\title{
EARLY MARGINAL ULCER FOLLOWING ROUX-EN-Y GASTRIC BYPASS UNDER PROTON PUMP INHIBITOR TREATMENT - prospective multicentric study
}

\author{
Arthur Belarmino GARRIDO Jr. ${ }^{1}$, Marçal ROSSI ${ }^{2}$, Sizenando Ernesto LIMA Jr. ${ }^{3}$, \\ Antonio Sérgio BRENNER ${ }^{4}$ and Claudio Antonio Rufino GOMES Jr. ${ }^{5}$
}

\begin{abstract}
Context - Causal factors of gastrojejunal ulcers after Roux-en-Y gastric bypass include peptic acid secretion from the gastric pouch. Esomeprazole is a potent inhibitor of acid secretion. Objective - To assess the occurrence of dyspepsia and gastrojejunal ulcers within the first 2 months after Roux-en-Y gastric bypass during the use of esomeprazole. Methods - One hundred eighteen morbid obese subjects were submitted to Roux-en-Y gastric bypass. Preoperative upper gastrointestinal tract endoscopy was negative for H. pylori. All subjects received esomeprazole for 60 days after surgery. Results - Two weeks after surgery only 13 mild symptoms were reported. After 2 months, 17 also moderate complaints were registered. Endoscopy around the 60th day showed esophagitis in $10(8.5 \%)$, hiatal hernia in $2(1.7 \%)$, foreign body in the anastomotic line in $12(10.2 \%)$ and gastrojejunal ulcers was observed in $9(7.6 \%)$ subjects, 2 of which had a suture material or metallic staple granuloma in the gastrojejunostomy. Ten subjects took nonsteroidal anti-inflammatory drugs at least once during study, but none of them developed ulcer. None of the subjects with ulcer had dyspeptic symptoms. Conclusion - The incidence of ulcer in the gastrojejunal anastomosis within the first 2 months following Rouxen-Y gastric bypass under proton pump inhibitors is considerable. It was not related to the use of non-steroidal anti-inflammatory drugs, highlighting the possibility of ischemia and foreign body as causal factors. The ulcers were asymptomatic, and all post-surgical dyspeptic symptoms were moderate in severity.
\end{abstract}

HEADINGS - Gastric bypass. Anastomosis, Roux-em-Y. Stomach ulcer. Dyspepsia.

\section{INTRODUCTION}

The Roux-en-Y gastric bypass (RYGBP) is the most used bariatric surgical procedure worldwide ${ }^{(5,14)}$. It may be performed with several technical variables, such as the pouch capacity, the presence or not of a contention band in the pouch exit, the length of the alimentary and biliopancreatic loops, and the use of conventional or videolaparoscopic access $\left.{ }^{(6,9}, 15,22,24\right)$ (Figures 1 and 2).

All technical variants have in common the anastomosis of a reduced gastric pouch (Fig.1-a) to a small bowel "Y" loop (Fig.1-b), which is not reached by the alkaline fluid secreted by the liver and the pancreas, being therefore exposed to the peptic action of the acid juice produced by the gastric pouch, although in small amount.

The number of bariatric procedures is continually increasing. The estimated number in USA was 140.000 per year ${ }^{(5)}$, and in Brazil 20.000 every year ${ }^{(8)}$. The cumulative experience has shown that, in addition to the benefits, there is also the risk of adverse effects, both in short and long terms. Some of the complications start in the gastrointestinal tube within the first post-surgical months, causing symptoms like nausea, vomiting, epigastric pain, abdominal pain and bleeding, which may be due to peptic disorders, such as ulcers and erosions ${ }^{(1,}$ 10). The incidence of ulcer in the anastomosis (GJU) is variable in the literature, ranging from $1 \%$ to $16 \%$ after the RYGBP ${ }^{(3,7,20)}$. Ulcers may be caused by the peptic action of the acid juice from the gastric pouch acting on the small bowel not alcalinized by biliopancreatic juice ${ }^{(11)}$. During the immediate post-surgical period factors like ischemia caused by the sutures, foreign body reaction to the presence of synthesis material, and the use of non-steroidal anti-inflammatory drugs (NSAIDs) may play a role ${ }^{(7,20)}$. Considering all these possibilities, bariatric surgeons, trying to reduce such complications, usually prescribe proton pumb inhibitors (PPIs) during the post-surgical period. However, due to the small number of controlled studies in this field, the exact effect of this clinical practice, which only acts on the acid peptic factor, is unclear.

'Instituto Garrido, São Paulo, SP; ${ }^{2}$ Hospital Neomater, São Bernardo do Campo, SP; ${ }^{3}$ Hospital Mandaqui, São Paulo, SP; ${ }^{4}$ Hospital de Clínicas, Curitiba, PR; ${ }^{5}$ Hospital Santa Rita, São Paulo, SP, Brazil.

Correspondence: Prof. Arthur B. Garrido Jr. - Rua Dr. Rui Tavares Monteiro, 182 - 05653-020 - São Paulo, SP, Brazil. E-mail: abgarrido@uol.com.br 


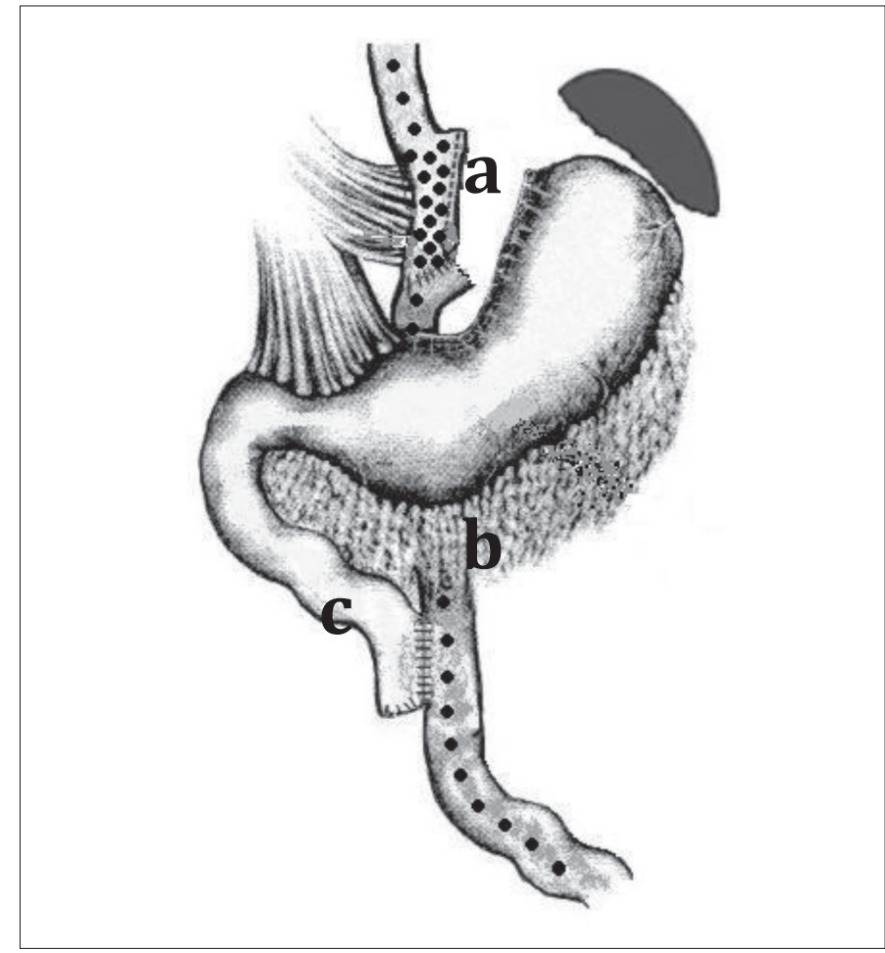

FIGURE 1. RYGBP

a - bag

$\mathrm{b}$ - feeding loop

c - biliopancreatic loop

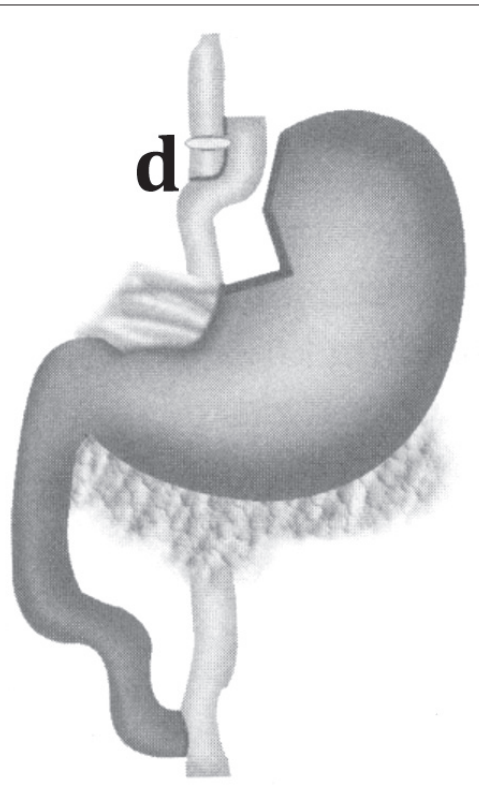

FIGURE 2. RYGBP with restraining band (d)

Esomeprazole is a known potent inhibitor of acid gastric secretion, increasing the gastric $\mathrm{pH}$ and potentially reducing symptoms and avoiding the occurrence of peptic lesions, even among NSAID users ${ }^{(17,21)}$.
This multicentric, prospective, non-randomized study aimed to assess the incidence of dyspeptic symptoms and GJU within the first 2 months of RYGBP surgery with the use of esomeprazole.

\section{METHOD}

During the period between November, 10th 2005 and July 2nd, 2006, 146 subjects with morbid obesity were submitted to surgery ${ }^{(18)}$ in four bariatric centers. A total of 28 subjects were not enrolled because they did not fulfill all inclusion criteria or were not compliant with the use of the drug or were lost to follow-up. Thus, 118 subjects were assessed according to the established protocol. Table 1 presents the subjects pre-surgical features.

TABLE 1. Pre-surgical features of 118 subjects with morbid obesity

\begin{tabular}{lcc}
\hline Gender & 18 males & 100 females \\
\hline Age $(\text { years })^{*}$ & & $42(11)$ \\
BMI $\left(\mathrm{kg} / \mathrm{m}^{2}\right)^{*}$ & & \\
\hline
\end{tabular}

mean (standard deviation)

The inclusion criteria for this study were: at least 18 years of age, negative or pre-surgically eradicated Helicobacter pylori, no history of neoplasms, upper gastrointestinal tract ulcers and/or gastroduodenal erosions, as shown by the upper gastrointestinal tract endoscopy. The exclusion criteria were: any contraindication for RYGBP surgery, any contraindication for the use of omeprazole and other similar drugs, any reason which makes it impossible to perform an upper gastrointestinal tract endoscopy, suspected gastrinoma or hypergastrinemia, and previous esophageal-gastroduodenal surgery. All women with childbearing potential were required to have a negative pregnancy test.

Similar techniques were used for all procedures performed in the study (Figures 1 and 2). A silicon embracing band was used in $113(95.8 \%)$ cases, but not in $5(4.2 \%)$ subjects. Laparotomy was performed in $74(62.9 \%)$ subjects, and the videolaparoscopic access was used in $44(37.1 \%)$ subjects. Surgical steps: 1. Vertical gastric division with a linear stapler up to esophageal-gastric transition creating a $20 \mathrm{~mL}$ functioning pouch. 2. Continuous seromuscular suture engraving the staple line in the excluded stomach and in the pouch. 3. Placement of the silicon band 2 to $3 \mathrm{~cm}$ above the gastrojejunal anastomosis (not performed in five cases). 4 . Wide termino-lateral gastrojejunal anastomosis $(>1.5 \mathrm{~cm})$. Open surgery: two layer sutures including a total continuous suture using 2-0 chromic catgut and a continuous seromuscular suture using 3-0 polyglactine. Laparoscopic surgery: a linear stapler was combined $( \pm 3 \mathrm{~cm})$ with total and seromuscular continuous sutures using 3-0 PDS. 5. Jejunal loop stub interposition between the pouch and the excluded stomach up to the band, fixing it to the pouch without reaching the esophageal-gastric transition level. 6. Roux-en-Y loop (100 to $120 \mathrm{~cm}$ ). 7. Biliopancreatic loop, 30 to $70 \mathrm{~cm}$ from the duodenojejunal flexure to the jejunojejunal anastomosis. 8 . 
Two layers jejunojejunal anastomosis. In open surgery, total continuous suture with 3-0 chromic catgut and continuous seromuscular suture using 3-0 polyglactine were used. In laparoscopic surgery, total and seromuscular continuous sutures using 3-0 PDS were combined with a linear stapler. 9. In open surgery the alimentary loop was transposed to the supramesocolic level through the transverse mesocolon. This step was pre-colic in the laparoscopic technique.

Subjects started receiving "per os" a $20 \mathrm{mg}$ daily tablet of esomeprazole dispersed in water within 72 hours after surgery. The medication was maintained for 60 days. Any patient skipping more than 1 day without taking the drug was withdrawn. The 118 subjects who fulfilled the inclusion criteria and followed the procedures of the protocol were studied.

Clinical assessment was performed in the 3 rd post-surgical day (POi), and then two more clinical assessments were performed until the end of the trial; the first between the 10th and the 15th post-surgical day (PO15), when the patient was still having a liquid diet and the second between the 55th and the 65th post-surgical day (PO60), with the patient receiving a solid diet since the 30th post-surgical day. Vital signs, body mass index (BMI) and gastrointestinal symptoms, such as heartburn, epigastric pain, nausea, vomiting and abdominal pain were registered.

An endoscopic examination of the esophagus, gastric pouch, gastrojejunal anastomosis and the proximal alimentary loop was performed within 5 days before or after the second clinical assessment.

SPSS 13.0 and Minitab 14.0 softwares were used for data summary and data analysis, in addition to an Excell program for categorized analyses with repeated measures. Samples of populations with normal distribution according to the Kolmogorov-Smirnov test were compared using the Student $t$-test and ANOVA for repeated measures ${ }^{(25)}$, while ANOVA was used for categorized variables with repeated measures ${ }^{(4 .}$ 19). The significance level for all tests was $5 \%$.

All subjects provided the signed Informed Consent. The study was performed according to the principles of the Declaration of Helsinki, adapted in 1964 and amended in 1996.

\section{RESULTS}

Post-surgical clinical signs (POi and PO60) are presented in Table 2 and show significantly reduced heart rate, systolic blood pressure and BMI values at PO60.

TABLE 2. Comparison of mean heart rate, systolic and diastolic blood pressure and body mass index values as measured within 72 hours and 55 to 65 days post-surgery

\begin{tabular}{lcccc}
\hline & 72 hours & $55-65$ days & Difference $(\%)$ & $\boldsymbol{P}^{* *}$ \\
\hline HR $($ beat $/ \mathrm{min}) *$ & $81.9(8.6)$ & $77.3(6.5)$ & $-5.6 \%$ & $<0.001$ \\
sBP $(\mathrm{mm} \mathrm{Hg}) *$ & $131.1(15.4)$ & $127.1(12.4)$ & $-5.6 \%$ & 0.012 \\
dBP $(\mathrm{mm} \mathrm{Hg})^{*}$ & $82.6(9.3)$ & $82.2(7.9)$ & $0 \%$ & 0.343 \\
BMI $\left(\mathrm{kg} / \mathrm{m}^{2}\right)^{*}$ & $43.0(5.5)$ & $36.8(5.2)$ & $-14.3 \%$ & $<0.001$ \\
\hline
\end{tabular}

* mean (standard deviation)
Gastrointestinal symptoms starting after surgery and recorded at PO15 and PO60 are presented in Table 3.

TABLE 3. Comparison between subjects with symptoms 10-15 days and 55-65 days post-surgery

\begin{tabular}{lccc}
\hline Symptoms & $10-15$ & $55-65$ & $\boldsymbol{P}^{*}$ \\
\hline Epigastric pain & $0(0.0 \%)$ & $1(0.8 \%)$ & 0.081 \\
Heartburn & $0(0.0 \%)$ & $5(4.3 \%)$ & 0.023 \\
Nausea & $8(6.8 \%)$ & $2(1.7 \%)$ & 0.054 \\
Vomiting & $1(0.8 \%)$ & $6(5.1 \%)$ & 0.059 \\
Abdominal pain & $4(3.4 \%)$ & $1(0.8 \%)$ & 0.081 \\
\hline
\end{tabular}

* ANOVA comparative test for repeated categoric measurements

Epigastric pain, heartburn, nausea, vomiting and abdominal pain had low incidences, of less than $7 \%$. There was no significant difference of frequency between PO15 and PO60, except for heartburn, which had a higher prevalence at $\mathrm{PO} 60$.

Pre-surgical endoscopy tests showed the presence of esophagitis in $25(21.2 \%)$, hiatal hernia in $15(12.7 \%)$, and gastritis in $68(57.7 \%)$ subjects. PO60 endoscopy showed the presence of esophagitis in $10(8.5 \%)$ subjects, 4 of whom had already had these findings in the pre-surgical exam; hiatal hernia in $2(1.7 \%)$ and suture line or staple foreign bodies in the anastomotic line in $12(10.2 \%)$ subjects.

GJU was observed in nine subjects $(7.6 \%$, calculated $95 \%$ confidence interval, 3.5\%-14.0\%). All were placed over or adjacent to the gastrojejunostomy. Three of them were in phase A1, three in A2 (Figure 3) and three in S1 (Figure 4). Diameters varied from 0.3 to $1.6 \mathrm{~cm}$. Suture material was present in the base of the ulcer in one case, and in another there was a staple in the ananstomotic line near the ulcer (Figure 4). In this case the operation was performed by laparoscopy, combining stapler and manual sutures for the anastomosis. No foreign body was observed in the remaining cases. No ulcer was observed in the vertical staple line of the gastric pouch. None of these nine subjects reported epigastric pain, heartburn, nausea, vomiting, or abdominal pain.

A total of $10(8.5 \%)$ of the 118 subjects used NSAIDs at some time point during the study. None of them presented ulcers at the endoscopy. NSAID therapy was irregularly taken, 2 to 7 times weekly, in the post-surgical period. One patient reported NSAID use before surgery, and sporadic use at PO15 and PO60.

\section{DISCUSSION}

The analysis of the results showed a significant loss of weight within the 2 first months after surgery. The significantly reduced systolic blood pressure and heart rate among these subjects, who frequently have impaired cardio-circulatory function were associated to the overall reduced weight ${ }^{(2,12,13,16,23)}$. Another general observation was that within the 2 first months after surgery, digestive symptoms, such as nausea, vomiting, heartburn, abdominal 


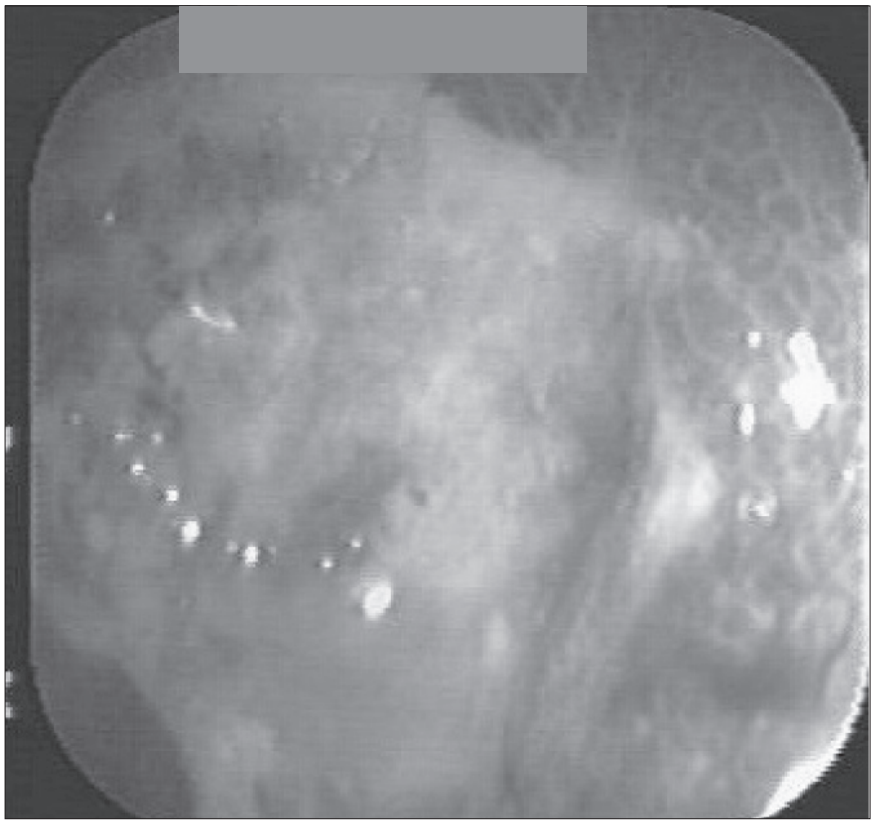

FIGURE 3. Ulcer (phase A2) in the gastrojejunostomy 60 days after RYGBP

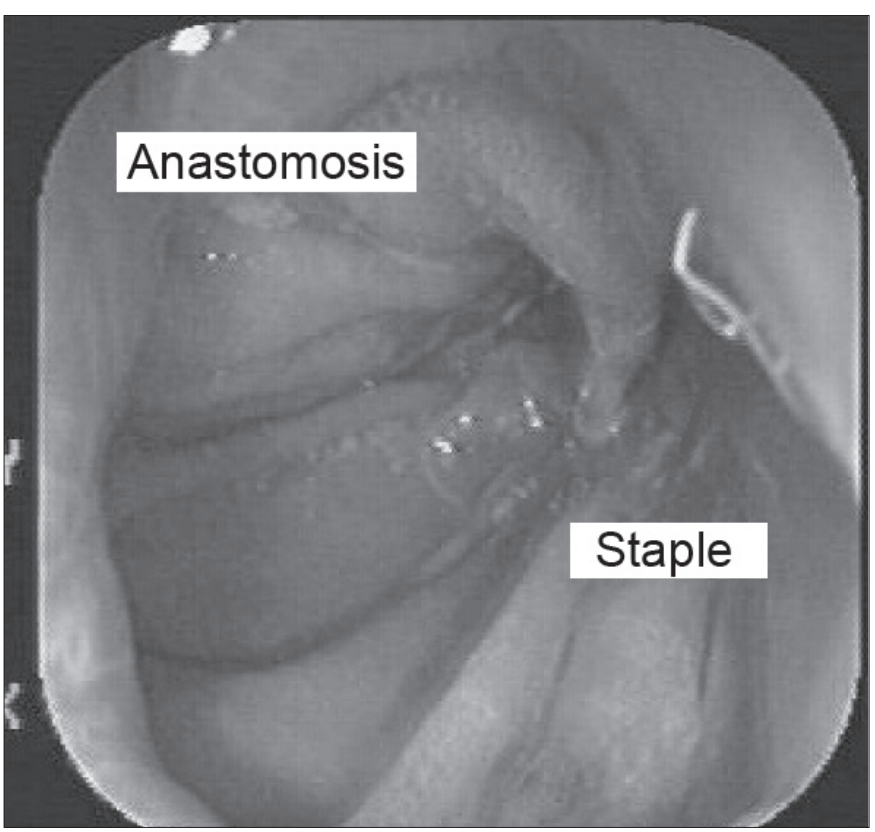

FIGURE 4. Marginal ulcer (phase S1) near staple in the anastomotic line

pain and epigastric pain, had a relatively low frequency $(<7 \%)$, considering the huge anatomic and functional changes caused by the RYGBP. The use of PPI within the 1st month after surgery since to be useful to reduce the occurrence and severity of dyspeptic postoperative symptoms in our series.

PO60 endoscopic findings showed a lower incidence of esophagitis, hiatal hernia and gastritis as compared to presurgical findings. For esophagitis and gastritis the explanation may be the low gastric juice production by the small gastric pouch, the effect of the Roux-en-Y loop, avoiding alkaline reflux, and the blockade of acid secretion production due to the use of esomeprazole. The loss of weight, and the consequently lower intra-abdominal pressure, may explain the lower frequency of hiatal hernia.

On the other hand, the incidence of ulcer observed in the anastomotic mouth was expressive: $7.6 \%$. This finding is surprising, since none of the affected subjects reported any digestive symptoms. Also, no subject of this group used NSAIDs in the post-surgical period, excluding these drugs as etiologic factor. Nonetheless, the low gastric juice volume produced by the small pouch, added to esomeprazole's acid blockade reduces the importance of a peptic acid cause for these ulcers. Other causes should therefore be considered, including mucosal ischemia caused by the anastomosis and the foreign body role of the suture material and the staples. This last hypothesis is supported by the high frequency of observed foreign bodies in the anastomotic line at PO60: $12(10,2 \%)$ cases. There was a suture material or a staple in two of the identified ulcers. Barroso et al. ${ }^{(3)}$ reported, in endoscopic tests performed 2 to 6 months after the RYGBP, a $4.7 \%$ rate of ulcers in the anastomosis, associated with severe symptoms. Sapala et al. ${ }^{(20)}$ observed no ulcer 1 year after RYGBP, and only one case 3 years later. These reports, in addition to our findings, may indicate a progressively reduced incidence of ulcers following the ischemic suture period regression. The presence of ulcer symptoms observed by Barroso et al. ${ }^{(3)}$ may be explained by the suppression of PPI 2 months after surgery adopted by him as routine.

\section{CONCLUSIONS}

We conclude that RYGBP results in significant body weight loss after 60 days. There is also a significant improvement in some cardio-circulatory function markers, with very mild digestive symptoms, at least during the use of PPI. However, the incidence of ulcer in the anastomotic mouth $(7.6 \%)$ during this period is expressive, considering that NSAID use was excluded. Mucosal ischemia and foreign body effect in the sutures may explain this rate. The use of PPI within the first months after surgery seems to be useful to reduce the occurrence and severity of ulcers and dyspeptic symptoms. 
Garrido Jr AB, Rossi M, Lima Jr S, Brenner AS, Gomes Jr CAR. Úlcera perianastomótica após derivação gástrica em Y-de-Roux mesmo em uso de inibidor de bomba de prótons - estudo prospectivo multicêntrico. Arq Gastroenterol. 2010;47(2):130-4.

RESUMO - Contexto - Sintomas dispépticos são comuns após derivação gástrica em Y-de-Roux. Podem decorrer de úlceras de boca anastomótica, cujos possíveis fatores causais incluem a secreção cloridropéptica da bolsa gástrica, isquemia, efeito de corpo estranho dos materiais de sutura e uso de antiinflamatórios não-esteróides. O esomeprazol é um redutor potente da secreção ácida, capaz de diminuir sintomas pépticos e evitar lesões mucosas, mesmo em pacientes usuários de antiinflamatórios não-esteróides. Objetivos - Estudo prospectivo não-randomizado procura avaliar a ocorrência de dispepsia e úlceras perianastomóticas nos 2 primeiros meses após derivação gástrica em Y-de-Roux. Métodos - Cento e dezoito obesos mórbidos foram operados em quatro centros de cirurgia bariátrica pela técnica de derivação gástrica em Y-de-Roux por laparotomia ou laparoscopia. À endoscopia digestiva alta, H. pylori estava ausente. Todos os operados tomaram $20 \mathrm{mg}$ de esomeprazol por dia do $3^{\circ}$ ao $60^{\circ}$ pós-operatório. Resultados - Entre o $10^{\circ}$ e o $15^{\circ}$ dia, nenhum paciente referiu epigastralgia ou pirose, um referiu vômitos moderados, quatro dor abdominal e oito náuseas. Entre o $55^{\circ}$ e o $65^{\circ}$ dia, três referiram epigastralgia leve, seis vômitos, um dor abdominal, dois náuseas e seis pirose. O exame endoscópico neste período revelou esofagite em 10 pacientes $(8,5 \%)$, hérnia hiatal em $2(1,7 \%)$ e corpo estranho nas linhas de sutura em $12(10,2 \%)$. Em nove pacientes (7,6\%) encontrouse úlcera de boca anastomótica ou adjacente a ela, em dois incluindo granuloma de fio de sutura ou de grampo metálico. Dez pacientes utilizaram alguma vez antiinflamatórios não-esteróides nos 2 meses de estudo, nenhum deles apresentando úlcera. Conclusões - A ocorrência de úlcera de boca anastomótica 2 meses após derivação gástrica em Y-de-Roux, é considerável, mesmo em uso de esomeprazol. Não houve relação com ingestão de antiinflamatórios não-esteróides, o que realça as possibilidades dos fatores isquemia e corpo estranho na gênese das lesões.

DESCRITORES - Derivação gástrica. Anastomose em Y-de-Roux. Úlcera gástrica. Dispepsia.

\section{REFERENCES}

1. Abell TL, Minocha A. Gastrointestinal complications of bariatric surgery: diagnosis and therapy. Am J Med Sci. 2006;331:204-8.

2. Alexander JK, Dennis EW, Smith WG, Amad KH, Duncan WC, Autin RC. Blood volume, cardiac output and distribution of systemic blood flow in extreme obesity. Cardiovasc Res Cent Bull 1962; 1:39-44.

3. Barroso FL, Oliveira-e-Silva LG, Valente DC. Ulcers and erosions after gastroplasty with silicone band and bypass [abstract]. Obes Surg. 2002;12:491.

4. Brunner E, Langer F. Nonparametric analysis of ordered categorical data in designs with longitudinal observations and small sample sizes. Biom J. 2000;42:663-75.

5. Buchwald H, William SE. Bariatric surgery training in the United States. Surg Obes Relat Dis. 2006;2: 52-6.

6. Capella JF, Capella RF, Mandec H, Nath P. Vertical banded gastroplasty-gastric bypass: preliminary report. Obes Surg. 1991;1:389-95.

7. Dallal MR, Bailey LA. Ulcer disease after gastric bypass surgery. Surg Obes Relat Dis. 2006;2:455-9.

8. Ferraz EM. Cirurgia bariátrica baseada em evidência. In: Cecconelo I, editor. Atualização em cirurgia do aparelho digestivo e coloproctologia. São Paulo: Frontis; 2006. p.115-20.

9. Fobi MAL, Lee H, Fleming AW. The surgical technique of the banded Roux-en-Y gastric bypass. J Obes Weight Regulation. 1989;8:99-102.

10. Foster A, Laws HL, Gonzalez QH, Clements RH. Gastrointestinal symptomatic outcome after laparoscopic Roux-en-Y gastric bypass. J Gastrointest Surg. 2003;7:750-3.

11. Hedberg J, Hedenstrom H, Nilsson S, Sundbom M, Gustavsson S. Role of gastric acid in marginal ulcer after gastric bypass. Obes Surg. 2005;15:1375-8.

12. Isomaa B, Almgren P, Tuomi T, Forsén B, Lahti K, Nissén M, Taskinen MR, Groop L. Cardiovascular morbidity and mortality associated with the metabolic syndrome. Diabetes Care. 2001;24:683-9.

13. Kenchaiah S, Evans JC, Levy D. Obesity and the risk of heart failure. N Engl J Med. 2002;347:305-13.
14. Korenkov M, Sauerland S, Junginger T. Surgery of obesity. Curr Opin Gastronterol. 2005;21:679-83.

15. Mason EE, Printen KJ, Hartford CE. Optimizing results of gastric bypass. Ann Surg. 1975;182:405-13.

16. McCloskey CA, Ramani GV, Mathier MA, Schauer PR, Eid GM, Mattar SG, Courcoulas AP, Ramanathan R. Bariatric surgery improves cardiac function in morbidly obese subjects with severe cardiomyopathy. Surg Obes Relat Dis. 2007;3:503-7.

17. Miner P Jr, Katz PO, Chen Y, Sostek M. Gastric acid control with esomeprazole, lansoprazole, omeprazole, pantoprazole and rabeprazole: a five-way crossover study. Am J Gastroenterol. 2003;98:2616-20.

18. NIH Conference. Gastrointestinal Surgery for Severe Obesity. Consensus Development Conference Panel. Ann Intern Med. 1991;115:956-61.

19. Rosa P. Análise não paramétrica de dados originais com medidas repetidas [dissertação]. São Paulo: IME - Universidade de São Paulo; 2001.

20. Sapala JA, Wood MH, Sapala A, Flake TM Jr. Marginal ulcer after gastric bypass: a prospective 3-year study of 173 subjects. Obes Surg. 1998;8:505-16.

21. Scheiman JM, Yeomans ND, Talley NJ, Vakil N, Chan FK, Tulassay Z, Rainoldi JL, Szczepanski L, Ung KA, Kleczkowski D, Ahlbom H, Naesdal J, Hawkey C. Prevention of ulcers by esomeprazole in at-risk subjects using non-selective NSAIDs and COX-2 inhibitors. Am J Gastroenterol. 2006;101: 701-10.

22. Torres JC, Oca C. Gastric bypass lesser curvature with distal Roux-en-Y. Bariatric Surg. 1987;5:10-5.

23. Vasan RS, Larson MG, Benjamin EJ, Evans JC, Levy D. Left ventricular dilatation and the risk of congestive heart failure in people without myocardial infarction. N Engl J Med. 1997;336:1350-5.

24. Wittgrove AC, Clark GW. Laparoscopic gastric bypass, Roux-en-Y technique and results in 75 subjects with 3-30 months follow up. Obes Surg. 1996;6:500-4.

25. Zar JH. Biostatistical analysis. New Jersey: Prentice Hall; 1999.

Received 28/1/2009. Accepted 21/7/2009. 